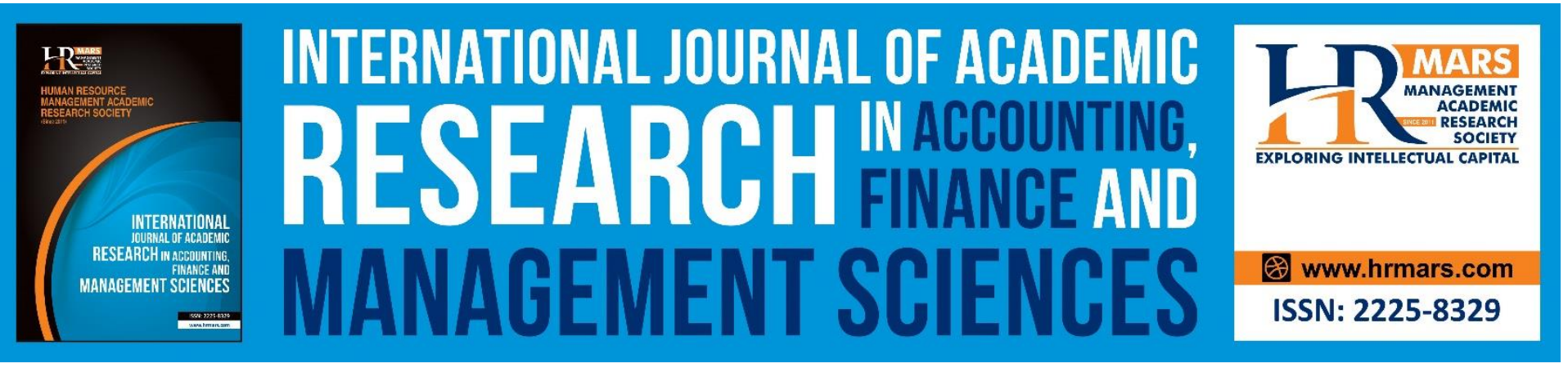

\title{
Integrated Reporting and Environmental, Social and Governance: A Study on Malaysian Banking Sector
}

\author{
Nooriha Mansor, Radziah Mahmud, Sunarti Halid, Rahayu Abdul Rahman \\ To Link this Article: http://dx.doi.org/10.6007/IJARAFMS/v11-i3/11094 $\quad$ DOI:10.6007/IJARAFMS/v11-i3/11094
}

Received: 18 July 2021, Revised: 21 August 2021, Accepted: 10 September 2021

Published Online: 27 September 2021

In-Text Citation: (Mansor et al., 2021)

To Cite this Article: Mansor, N., Mahmud, R., Halid, S., \& Rahman, R. A. (2021). Integrated Reporting and Environmental, Social and Governance: A Study on Malaysian Banking Sector. International Journal of Academic Research in Accounting Finance and Management Sciences, 11(3), 644-660.

Copyright: (c) 2021 The Author(s)

Published by Human Resource Management Academic Research Society (www.hrmars.com)

This article is published under the Creative Commons Attribution (CC BY 4.0) license. Anyone may reproduce, distribute, translate and create derivative works of this article (for both commercial and non-commercial purposes), subject to full attribution to the original publication and authors. The full terms of this license may be seen

at: http://creativecommons.org/licences/by/4.0/legalcode

\section{Vol. 11, No. 3, 2021, Pg. 644 - 660}

Full Terms \& Conditions of access and use can be found at http://hrmars.com/index.php/pages/detail/publication-ethics 


\title{
Integrated Reporting and Environmental, Social and Governance: A Study on Malaysian Banking Sector
}

\section{Nooriha Mansora, Radziah Mahmud ${ }^{\mathrm{b}}$, Sunarti Halida, Rahayu Abdul Rahman*a}

aFaculty of Accountanc, Universiti Tekhnologi MARA, Cawangan Perak, Kampus Tapah 35400, Tapah Road, Perak Darul Ridzuan, Malaysia, ' Faculty of Accountancy, Aras 1 \& 2 Bangunan FPA, Universiti

Tekhnologi MARA, Cawangan Selangor, Kampus Puncak Alam Bandar Bandar Puncak Alam, Selangor, Malaysia.

*Corresponding Author: rahay916@uitm.edu.my

\begin{abstract}
Unlike past research, which has primarily concentrated on Western countries, this study looks into the factors that influence corporate, social, and governance (ESG) environmental reporting among Asian companies. Currently, companies are inspired to report their progress to stakeholders regarding economic, social, and environmental factors, due to the rising demand for corporate transparency and sustainability. Hence. this study examines the effect of the integrated reporting disclosure (IRD) onto ESG score by employing a sample of 8 Malaysia's largest commercial banks from 2015 to 2019. Data is obtained from Thomson Reuters Eikon and regression analysis is carried out using the Statistical Package for the Social Sciences (SPSS, version 24). Result demonstrates that ESG score is affected by IRD, board tenure and bank size. The findings of this study are of interest to companies that are interested in implementing ESG and IRD for their own advantage, as well as regulatory agencies who believe ESG and IRD to be requirements for achieving national social and environmental goals.
\end{abstract}

Keywords: Integrated Reporting, Integrated Reporting Disclosure, Board of Directors, Environmental, Social and Governance

\section{Introduction}

Companies have sought internal improvement by implementing sustainable and socially responsible policies and reporting to remain competitive. It is beacause demands for corporate transparency and accountability to the environment, social reporting and governance (ESG) have increased dramatically especially during the Covid-19 pandemic as companies' ESG activities are closely being scrutinized. Hence, it is critical for them to perform well in their ESG assessments in order to get top ratings and the bar is likely to rise over time. Malaysian companies are encouraged to implement ESG as a corporate standard since it allows important facts to be disseminated to stakeholders relating to 
INTERNATIONAL JOURNAL OF ACADEMIC RESEARCH IN ACCOUNTING, FINANCE AND MANAGEMENT SCIENCES

Vol. 11, No. 3, 2021, E-ISSN: 2225-8329 @ 2021 HRMARS

the company's essential achievements. Among all these companies, larger cap companies have the urge to do more to manage their ESG risks and possibilities as international investors increasingly incorporate ESG issues into their investment decisions.

The ESG score considers the involvement of respective companies concerning environmental, social, and organizational governance activities. In other words, to know whether a company is formally and socially accountable to the community, it could be observed through a company's ESG score. Better ESG performance for a company reflects the company's social and environmental obligation, which provides more reliable information and stable stock price fluctuations in the market (Shakil et al., 2020). Companies with low minimum ESG performance are unstable in the market due to their irresponsible and unconcern nature. Thus, the board of directors (BOD) needs to be proactive in disseminating the company's information. They should concentrate on finding a balance between serving the needs of their stakeholders and being accountable to them, particularly while doing business during this new normal.

The determinants that influence ESG disclosure activity have been the subject to numerous investigations. Several studies consider the influence of corporate governance activities such as board size and independent directors' presence on the board of directors. Pertaining board size, large board sizes tend to enhance the ESG exposure scores of publicly traded airport companies (Ozcan, 2019). Further, using a data set of 366 Fortune 500 companies, Giannarakis (2014) also discovers that a larger board leads to a higher ESG disclosure score. As for independent directors, higher percentage of independent directors would raise the ESG disclosure score of a publicly traded airport company (Khaled et al., 2021).

When assessing ESG disclosure performance determinants, various variables generated from a company's financial statements have also frequently been employed in addition to corporate governance characteristics. The company's size is the most typical factor being employed. Larger companies tend to make more disclosures (Khaled et al., 2021; Ozcan, 2019; Velte, 2017) due to the availability of their human resources and size effects, which result in larger volumes of activity to be declared. Profitability is another financial indicator that is frequently utilised in comparable studies. There are studies that have found a favourable relationship between a company's ESG and company performance (Abdul Rahman \& Alsayegh, 2021; Bernardi \& Stark, 2018) while others have failed to find a statistically significant relationship between variables (Frias-Aceituno et al., 2013; Marston \& Polei, 2004).

Recently, due to stakeholders' request for better reporting, it has led to the demand for integrated reporting (IR). An integrated report is a concise reporting format based on a structure developed by the International Integrated Reporting Council (hereafter IIRC). Companies should adopt IR as it provides pertinent information about the companies' operations that would interest stakeholders while making their investment decisions. It conveys information relating to the company's activities in a cohesive manner that discusses the eight IR content elements from the IIRC context. Owing to its strategic significance to companies worldwide, IR has started to gather considerable attention. In a single disclosure document describing a business's financial and non-financial results, IR can address the growing needs of stakeholder's communications (Stubbs \& Higgins, 2012). IR seeks to replace the 
INTERNATIONAL JOURNAL OF ACADEMIC RESEARCH IN ACCOUNTING, FINANCE AND MANAGEMENT SCIENCES

Vol. 11, No. 3, 2021, E-ISSN: 2225-8329 ๔ 2021 HRMARS

earlier prevalent method of separating financial and sustainability knowledge by releasing a single comprehensive study in today's dynamic market (Jensen \& Berg, 2012). The IIRC states that incorporating financial and sustainability information would assist in entertaining the information needs of investors by offering a fuller and more balanced image of a business and its results. IR is futuristic as compared to the previous historical financial reporting approach. To enable more reliable results to be reported, the International IR Framework, which was first released in December 2013, was reviewed in January 2021 by the IIRC.

This study focuses on ESG and IR as they are the current phenomenon in business reporting, as more companies opt for this form of voluntary report. Based on a survey conducted by PWC Malaysia on the annual reports of 30 top firms in 2013, it points out that Malaysian companies have the basic elements or representations of IR but still has a long way to adopt IR (Accountants Today, 2014). Hence, this study aims to examine whether integrated reporting disclosure (IRD) has any influence on ESG score. Eight (8) Malaysian Commercial Banks for years between 2015 and 2019 were examined to determine the relationship between IRD and ESG. As it is easily affected by the economic cycle, the financial sector (banks) can be regarded as one of the riskiest investment sectors, especially with the unsettlingly fast global spread of Covid-19, which has sent financial markets into a tailspin, banks have been hit harder than other industries (Aldasoro et al., 2020). Overall, the pandemic poses a significant risk to the efficiency, survival, and growth of banks in developing countries, especially in those countries where banks play a dominant role in the economy (Barua \& Barua, 2020), and to avoid a large-scale and infectious banking crisis, urgent and creative policy steps are required. The more volatile the sector is, the more companies are driven to issue superior-quality annual reports to illustrate the possible advantages. Thus, the report on the review of these organizations' transparency that focuses on the encoding of economic, social, and environmental into a single text that is the IR would assist stakeholders to comprehend the overall performance of an organization during the financial year.

Following this first introduction section, this study is divided into four other main parts: the second section discusses on a literature review and hypothesis development under investigation; the third section is on methodology that specifies the sample and data collection method, dependent variable, independent variable and control variables that are being employed in this study; while the fourth section is on discussion and conclusion that elaborates on the findings, debates and conclusions.

\section{Literature Review and Hypothesis Development}

Disclosure of the information is common among companies to mitigate agencies and political costs and reduce asymmetries in information (Frias-Aceituno et al., 2013). Recently, the business world has gradually increased the disclosed information requirements via IR, that is, besides preparing financial statements, management reports, reports on corporate social responsibility and corporate governance reports are required to meet investors and other stakeholders' demands (García-Sánchez \& Noguera-Gámez, 2017). On top of that, management decision making around the world is gradually referring to ESG measures as the ESG criteria are a set of operational guidelines that investors and other stakeholders refer to for possible references. Employing IR and ESG could assist in building 'moral capital' for companies in providing consumer-like security to respective companies and safety measures to them, especially during market downturns (Godfrey, 2005), such as during the Covid-19 
INTERNATIONAL JOURNAL OF ACADEMIC RESEARCH IN ACCOUNTING, FINANCE AND MANAGEMENT SCIENCES

Vol. 11, No. 3, 2021, E-ISSN: 2225-8329 ๑ 2021 HRMARS

pandemic where practically every economy is confronting considerable drop in its economic performance.

According to the governance process based on stakeholder theory, a company is believed to have a responsibility to society's long-term demands and expectations, not simply to its shareholders per se. A company's mission should be to conduct business in ways that benefit the public and help reduce the negative consequences of their efforts, as long as engaging in such actions that are not illegal (Branco \& Rodrigues, 2007). This can be accomplished via balance attention among these various groups while making business decisions and selecting the plan that best balances their various rights (Smith \& Hasnas, 1999). Stakeholders, by definition, are those who are affected by or can affect a decision (Freeman, 1984, 2010) and they can either be external or internal stakeholders. Customers, suppliers, creditors, governments, financial institutions, and others indirectly related to the enterprise are examples of the former, while employees, managers, and shareholders are examples of the latter. At present, stakeholders would disregard companies in the marketplace for poor ESG performance. Investors, for instance, would not invest in companies with low ESG scores or having ESG controversies. In fact, they would even penalize companies that ignore environmental, social, and governance considerations and do not include ESG standards in their business operations (Shakil, 2021) as they are more attracted to a company's long-term practices than to its operational and financial gains. Thus, stakeholder theory can best explain the need to maintain an excellent ESG score and employ IRD as investing in them would raise shareholders' wealth as other stakeholders are keen to contribute to the company's success with the resources they avail (Freeman, 2010).

Additionally, stakeholders are now pressing companies to get involved in several topics outside their core business, and management has to refer to these ESG measures as ESG Scores state these additional initiatives (Baron, 2014). Among the initiatives include: meeting stakeholder knowledge needs and pushing organizational progress for more successful adaptation (Eccles \& Krzus, 2010); reducing reputational risks and assisting organizations in dismantling operational and reporting silos and strengthening structures and procedures; and enabling companies to make educated financial and non-financial decisions (Stubbs \& Higgins, 2012). In gist, IR and ESG are the 'in thing'. The effort of combining monetary and non-monetary information into a single report does require board skill and knowledge (Umar et al., 2020) and the quality of IR could have an impact on the ESG scoring of companies (Conway, 2019). Accordingly, the following hypothesis is deemed appropriate:

Hypothesis 1: There is a positive relationship between the degree of IRD and the ESG among the commercial banks in Malaysia.

\section{Methodology}

\section{Sample and Data Collection}

In conducting this study, 8 of Malaysia's largest commercial banks are selected namely Hong Leong Bank, Hong Leong Financial Group, AMMB Holdings, CIMB Group Holdings, Malayan Banking, Public Bank, RHB Bank Bhd and Alliance Bank Malaysia as they are major players in the local banking system. The data for each variable is for the years between 2015 and 2019. Since all of these banks have provided the necessary data during these previous years, these banks are selected. Financial, corporate governance data as well as ESG score are collected from Thomson Reuters Eikon. 


\section{Dependent Variable}

Environmental, social, and governance (ESG) is the dependent variable for this study. ESG score of Refinitiv Eikon has been selected for this study as it is the most reliable data source of ESG metrics (Bătae et al., 2021). It employs 68 environmental, 62 social, and 56 corporate governance indicators to measure ESG performance, and assigns scores in percentages ranging from 0 to 100 (Refiniti Eikon Datastream, 2021). There are 20 resource consumption metrics, 28 emissions metrics, and 20 innovation metrics among the environmental indicators (Refiniti Eikon Datastream, 2021). Thirty labour force metrics, eight civil liberties metrics, fourteen community metrics, and ten (10) merchandise accountability metrics make up the social indicators (Refiniti Eikon Datastream, 2021). Thirty-five (35) management metrics, twelve (12) shareholder metrics, and nine (9) corporate social responsibility strategy metrics are among the governance indicators (Refiniti Eikon Datastream, 2021). ESG scores of 0 to 25 are considered poor ESG performance, whilst ESG scores of 75 to 100 are considered to be great ESG indicators (Refiniti Eikon Datastream, 2021).

\section{Independent Variables}

Analyzing the information quality of public reports yield the independent variable reflecting information disclosure practice. A divulgation index was generated by concentrating on IIRC (2021) IR system's content fundamentals. Similar to the Kılıç and Kuzey (2018) approach. Table 1 shows the fifty (50) items in seven (7) categories of the disclosure index. This study uses content analysis to examine the degree of IRD among the surveyed companies. As a result, the annual report's narrative sections have been thoroughly examined. The most common form of content analysis is a nonweighted disclosure approach that examines each item's presence or absence (Krippendorff, 2004) by assigning a score of 1 for presence and 0 if otherwise.

Table 1. Integrated Reporting Items

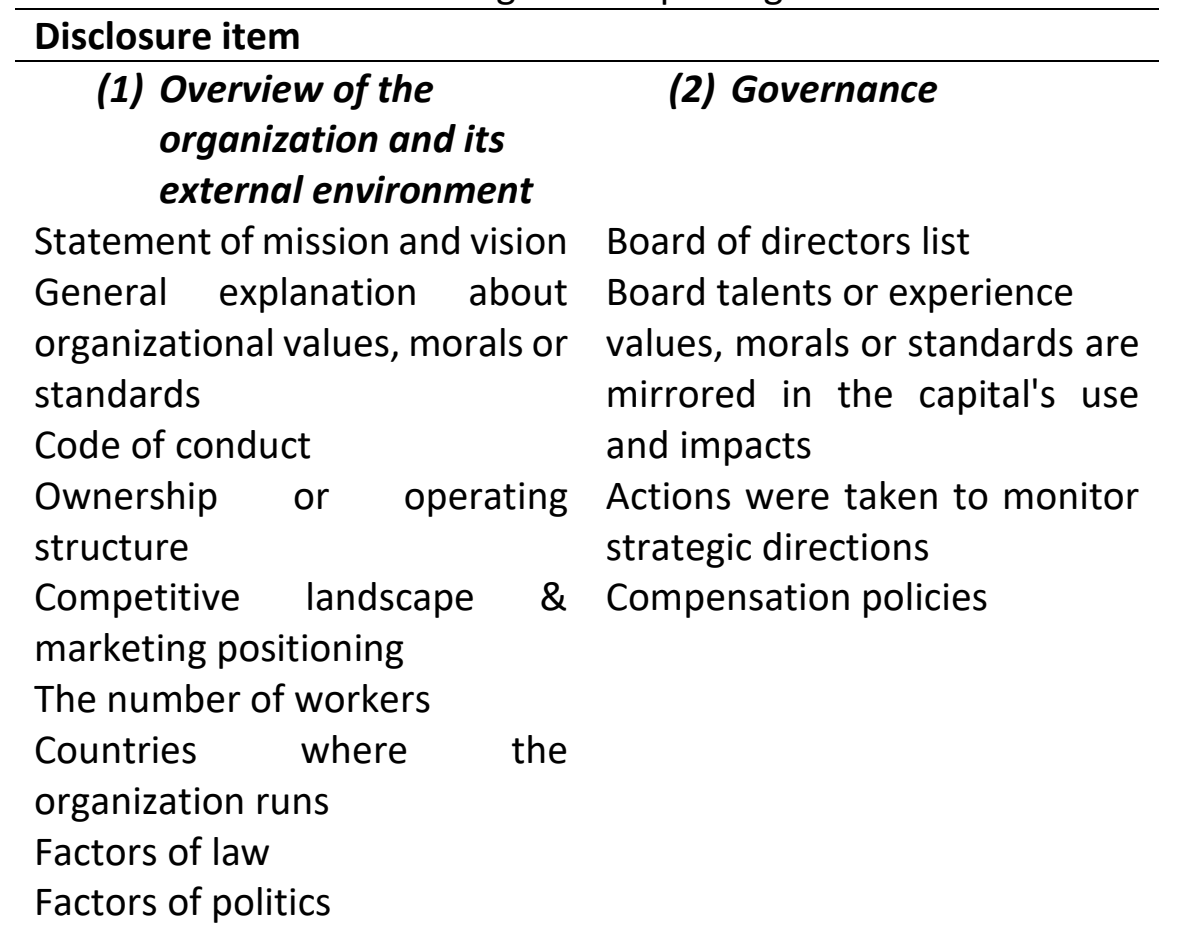


Social determinants

Forces of the market

Main Stakeholders

Environmental Factors

\begin{tabular}{ll}
\hline \multicolumn{1}{c}{ (3) Business Model } & $\begin{array}{c}\text { (4) Risk and opportunities } \\
\text { Important inputs }\end{array}$ \\
Differentiation of products & Internal/external risk \\
Marketing and distribution & \\
channels & \\
After-sale assistance & \\
Innovation & \\
Training for employees & \\
Essential products and services & \\
Greenhouse gas emissions \\
Wasted water \\
Morale among workers \\
Organizational reputation \\
Image of the company \\
Cash Flows and Revenue \\
contentment of customers \\
Rise in capital (generate value) \\
Decline in capital (reduce value)
\end{tabular}

(5) Allocation of Resources and Strategy

Short, medium, and long-term strategic aims (no time frame) Strategy objectives for the short, medium and long term (with time)

It has strategies in place or plans to implement to attain those strategic goals.

Achievements and desired results are measured.

Understanding of the organization's ability to adapt to change in order to meet its objectives

The connection between significant capitals and strategies
(6) Performance

KPIs on financial indicators

KPIs combining financial and non-financial metrics (i.e. The ratio of GHG emissions to sales) Performance comparisons between the past and the present

Benchmarking regionally and industrially

Financial consequences of significant effects on other capital 


\section{(7) Outlook}

Future predictions or arguments for the unknown Forecasts for Key Performance Indicators Assumptions used in connection with the forecast Relationships between current performance and the future prospects of the company

Adapted from Merve Kılıç and Cemil Kuzey (2018)

\section{Control Variables}

The control variables include the composition of the board of directors, bank size and profitability. As the company's governing body, the directors are responsible for defending the interests of numerous stakeholders, for example, through information distribution. Three elements of board characteristics, the board size, board independence and board tenure, are found to impact the ESG in previous studies. The BOD is a mechanism for corporate governance which determines the company's policies and strategies. Due to the BODs' supervisory role, they can assist companies in improving information disclosure. Consequently, the attributes of a board of directors may have a substantial effect on a company's transparency. Akhtaruddin et al. (2009) state that a board of directors is an important governance tool for increasing accountability and voluntary company disclosures as better monitoring, after all, will result in the public release of vast amounts of corporate data. According to the previous literature, there is no consistent results between board size and disclosure (Songini et al., 2021; Kılıç \& Kuzey, 2018). Husted \& de Sousa-Filho (2019) find a positive and significant effect of board size on ESG, while Orazalin (2019) and Sankara et al. (2017) could not find any significant impact of board size and ESG and CSR disclosure.

Next an independent board is seen as a necessary mechanism for reining in managers and ensuring that shareholders' objectives are met. The involvement of independent non-executive directors also contributes to the board's independence. However, there is no consistent outcome for disclosure and independence of directors as there seem to be mixed results. Chau and Gray (2010) state that boards with higher proportions of independent directors inspires higher ESG disclosure level and greater commitment in ESG activities. Karamanou and Vafeas (2005) and Cheng and Courtenay (2006) also find similar results. While Songini et al. (2021) find otherwise. Further, board tenure is the length of time a person serves as a director in an organization (Shiah-Hou \& Cheng, 2012). Longer board tenure may be advantageous as board members have more knowledge about ESG activities and have better collaboration (Rutherford \& Buchholtz, 2007). On the other hand, Handajani et al., (2014) state that the longer the board members' period of service, the lesser the CSR activity and thus its disclosure.

Besides the board of directors, the study also includes two other control variables representing bank size and profitability. One of the most common criteria used to determine the extent of business disclosures is the company's size, where in this study, it refers to the bank's size. Larger company size 
INTERNATIONAL JOURNAL OF ACADEMIC RESEARCH IN ACCOUNTING, FINANCE AND MANAGEMENT SCIENCES

Vol. 11, No. 3, 2021, E-ISSN: 2225-8329 @ 2021 HRMARS

is able to report more information about their investment in ESG as they have sufficient resources and facilities (Shakil et al., 2020). Gul and Leung (2004) and Luna Sotorrío and Fernández-Sánchez (2010) have also found a positive relationship between company size and voluntary information disclosure. Next is profitability where it looks at the performance of the organization. Even though previous research has usually found a favourable relationship between a company's ESG and company performance (Aboud \& Diab, 2018; Bernardi \& Stark, 2018), most studies have failed to find a statistically significant relationship between variables (Shonhadji, 2018; Welbeck et al., 2017; Marston \& Polei, 2004; Prencipe, 2004; Frias-Aceituno et al., 2013). In comparison, Qiu et al. (2016) find no relationship between ESG and company performance.

For the control variables, the operationalizations are as per Table 2.

Table 2: Definition and Operationalization of Control Variables

\begin{tabular}{|c|c|c|}
\hline $\begin{array}{l}\text { Control } \\
\text { Variables }\end{array}$ & Definition & Operationalization \\
\hline BSIZE & Board size & $\begin{array}{l}\text { Number of executive and non-executive board } \\
\text { members (Frias-Aceituno et al., 2013; Velte, 2017; } \\
\text { Riyadh et al., 2019) }\end{array}$ \\
\hline BIND & Board independence & $\begin{array}{l}\text { Non-executive directors as a percentage of total } \\
\text { directors (Anazonwu et al., 2018; Riyadh et al., 2019) }\end{array}$ \\
\hline BTEN & Board tenure & $\begin{array}{l}\text { Number of years holding the post as board members } \\
\text { (Frias-Aceituno et al., 2013; Velte, 2017) }\end{array}$ \\
\hline FSIZE & Bank size & Total asset logarithm (Dhole et al., 2019) \\
\hline PROF & Profitability & Return on asset (Li et al., 2019) \\
\hline
\end{tabular}

In the final section, findings for this study are being elaborated and it ends with a conclusion.

\section{Discussion and Conclusion \\ Findings and Discussion \\ Descriptive Statistics}

This study had done normality test prior to performing any additional tests. This study assessed for multicollinearity by using variance inflation factors (VIF) and Pearson correlation coefficients. VIF result in Table 3 indicates that the highest VIF value of 5.000 is for board tenure (BTEN), and the board size has the lowest VIF value of 1.458. Since the VIF value does not exceed the threshold value of 10 , it indicates no multicollinearity issues between the variables used in this study (Pallant, 2020). Table 3 tabulates the descriptive statistics for the variables used in this study. The results show that, on average, the environment, social and governance (ESG) score is 54.908 and the variation which is shown by standard deviation of 15.74 is regarded as high. Referring to ESG Scores guidance issued by Refiniti Eikon Datastream (2021), banks in Malaysia are generally graded as B indicating that while the banks are performing relatively good in terms of environment, social and governance, they have reported material ESG data to the public above the average degree of transparency. The ranges of ESG score are from a minimum of 28.805 (grade C-) to a maximum of 83.277 (grade A). The findings show while a bank is classified as performing satisfactorily and have moderate degree of transparency 
INTERNATIONAL JOURNAL OF ACADEMIC RESEARCH IN ACCOUNTING, FINANCE AND

MANAGEMENT SCIENCES

Vol. 11, No. 3, 2021, E-ISSN: 2225-8329 @ 2021 HRMARS

in disclosing material ESG data, another bank have excellent relative ESG performance and have high degree of transparency in disclosing material ESG data. The huge gap between the grade is indicated by high standard deviation.

This study finds that the degree of IRD of Malaysian banks is within the range of 18.000 and 46.000 . The lowest range is obtained by a bank in 2015. Low degree of IRD could be due to less awareness on the importance of IR in that year since the IR framework has only been issued in December 2013. The average IRD is $\mathbf{3 8 . 6 0 0}$ and the variation in IRD is low as indicated by standard deviation of 5.952. The Malaysian banks have at least 5 directors and maximum of 12 directors. On average, the banks have 9 directors and around 55\% of the board of directors' members are independent directors. The general board tenure in Malaysian banks is 8.099 years with minimum and maximum board tenure of 3.286 years and 18.333 years respectively. In relation to the firm characteristics, it is also found that there is high variance of the total assets for the Malaysian banks as indicated by the standard deviation of RM222,221 million. Even though the minimum total assets of the banks under review are only RM53,142 million, the maximum total assets are RM834,413 million which suggest high degree of variability in the reported total assets by the banks. The average total assets of the banks are found to be RM316,261 million. In terms of profitability of the bank which is measured using return of assets (ROA), the results indicate that the average ROA of the sample is $1.064 \%$. With a low variability in profitability as shown by the standard deviation of 0.209 , the range of ROA of the banks is between $0.627 \%$ and $1.434 \%$.

Table 3: Descriptive Statistics

\begin{tabular}{|c|c|c|c|c|c|}
\hline & Mean & Min & Max & Std Dev & VIF \\
\hline \multicolumn{6}{|c|}{28.80} \\
\hline ESG & 54.908 & 5 & 83.277 & 15.700 & \\
\hline \multirow{2}{*}{ IRD } & & 18.00 & & & \\
\hline & 38.600 & 0 & 46.000 & 5.952 & 1.715 \\
\hline BSIZE & 9.000 & 5.000 & 12.000 & 1.811 & 1.458 \\
\hline \multirow{2}{*}{ BIND } & & 30.00 & & & \\
\hline & 55.312 & 0 & 78.571 & 12.592 & 5.005 \\
\hline BTEN & 8.099 & 3.286 & 18.333 & 4.678 & 2.763 \\
\hline FSIZE (RM million) & 316261 & 53142 & 834413 & 222221 & 1.806 \\
\hline PROF & 1.064 & 0.627 & 1.434 & 0.209 & 2.648 \\
\hline \multicolumn{6}{|c|}{ ESG = Environment, Social and Governance, IRD = Integrated } \\
\hline \multicolumn{5}{|c|}{$\begin{array}{l}\text { Reportin Disclosure, BSIZE = Board Size, BIND = Board } \\
\text { Independence, BTEN = Board Tenure, FSIZE = Bank Size, PROF= }\end{array}$} & \\
\hline
\end{tabular}

Further analysis of the environment, social and governance (ESG) scores over the periods under study has been carried out and presented in Table 4. The results show that, on average, there is an increase on the ESG score for Malaysian banks over the years. The banks obtain 45.209 (grade $\mathrm{C}+$ ), 48.938 (grade C+), 55.244 (grade B-), 59.968 (grade B) and 65.183 (grade B) in 2015, 2016, 2017, 2018 and 2019 respectively. Based on the grading of ESG scores, the banks have moved from grade $\mathrm{C}+$ that denotes "satisfactory relative performance and moderate degree of transparency in reporting 
INTERNATIONAL JOURNAL OF ACADEMIC RESEARCH IN ACCOUNTING, FINANCE AND MANAGEMENT SCIENCES

Vol. 11, No. 3, 2021, E-ISSN: 2225-8329 @ 2021 HRMARS

material ESG data publicly" (Refiniti Eikon Datastream, 2021) to grade B that denotes "good relative ESG performance and above average degree of transparency in reporting material ESG data publicly" (Refiniti Eikon Datastream, 2021). Table 4 indicates that four banks namely B1, B3, B5 and B7 have improved their ESG scores over the five years period under review. The trend for the remaining banks is not consistent. The ESG score of B2 has decreased slightly in the year 2016 from 62.185 to 61.149. The score has improved continuously to 68.641 and 71.302 in 2017 and 2018 respectively. In 2019, the ESG score for B2 is 76.591. While the ESG score of B4 has increased in 2016 from 29.890 to 41.083, the score has decreased to 34.105 in 2017 before it goes up to 45.440 in 2018 and it falls again to 43.119 in 2019. With regards to B6, its ESG score has improved in 2016 from 49.140 t0 50.883. The score has decreased to 30.523 in 2017 before it goes up to 35.031 and 40.364 in the year 2018 and 2019 respectively. Similar to B2, its ESG score has diminished from 35.382 in 2015 to 28.805 in 2016. However, the ESG score increases gradually to 54.821, 61.063 and 64.256 in the year 2017, 2018 and 2019 respectively. Even though the trend of ESG scores among the banks is inconsistent, the overall ESG score indicates continuous improvement in ESG performance and transparency in disclosing material ESG.

Table 4: Analysis on ESG Scores Based on Individual Bank

\begin{tabular}{|c|c|c|c|c|c|c|c|c|c|}
\hline & B1 & B2 & B3 & B4 & B5 & B6 & B7 & B8 & AVERAGE \\
\hline \multicolumn{10}{|l|}{ FY2015 } \\
\hline Score & 35.199 & 62.185 & 39.849 & 29.890 & 45.434 & 49.140 & 64.593 & 35.382 & 45.209 \\
\hline Grade & $C$ & B & C & $\mathrm{C}-$ & $\mathrm{C}+$ & $\mathrm{C}+$ & $B$ & C & $\mathrm{C}+$ \\
\hline \multicolumn{10}{|l|}{ FY2016 } \\
\hline Score & 39.854 & 61.149 & 53.460 & 41.083 & 46.020 & 50.883 & 70.250 & 28.805 & 48.938 \\
\hline Grade & C & B & B- & C & $\mathrm{C}+$ & B- & $\mathrm{B}+$ & C- & $\mathrm{C}+$ \\
\hline \multicolumn{10}{|l|}{ FY2017 } \\
\hline Score & 54.877 & 68.641 & 71.838 & 34.105 & 52.698 & 30.523 & 74.450 & 54.821 & 55.244 \\
\hline Grade & B- & $\mathrm{B}+$ & $\mathrm{B}+$ & C & B- & C- & $\mathrm{B}+$ & B- & $B-$ \\
\hline \multicolumn{10}{|l|}{ FY2018 } \\
\hline Score & 59.625 & 71.302 & 63.749 & 45.440 & 61.015 & 35.031 & 82.522 & 61.063 & 59.968 \\
\hline Grade & B & $\mathrm{B}+$ & $\mathrm{B}+$ & $C$ & B & C & A- & B & B \\
\hline \multicolumn{10}{|l|}{ FY2019 } \\
\hline Score & 76.113 & 76.591 & 61.248 & 43.119 & 76.493 & 40.364 & 83.277 & 64.256 & 65.183 \\
\hline Grade & A- & A- & B & $\mathrm{C}+$ & A- & C & A & B & B \\
\hline
\end{tabular}

\section{Correlation Matrix}

Table 5 presents the correlations matrix of the dependent, independent and control variables used in the study. The positive and significant correlation between IRD and ESG suggests that banks that have higher degree of IRD are more likely to achieve higher ESG score. In addition, higher ESG score banks tend to have higher percentage of independent directors $(p=0.457)$, a shorter board tenure $(p=-0.308)$ and larger size as measured by total assets $(p=0.673)$. This study finds that IRD and bank size (FSIZE) are positively correlated. 
INTERNATIONAL JOURNAL OF ACADEMIC RESEARCH IN ACCOUNTING, FINANCE AND MANAGEMENT SCIENCES

Vol. 11, No. 3, 2021, E-ISSN: 2225-8329 @ 2021 HRMARS

Table 5: Correlation Matrix

\begin{tabular}{lrrrrrrr}
\hline & \multicolumn{1}{c}{ ESG } & \multicolumn{1}{c}{ IR } & \multicolumn{1}{c}{ BSIZE } & BIND & BTEN & FSIZE & PROF \\
\hline ESG & 1 & & & & & & \\
IRD & $* * * 0.682$ & 1 & & & & & \\
BSIZE & 0.244 & -0.014 & 1 & & & & \\
BIND & $* * * 0.457$ & 0.197 & $* 0.285$ & 1 & & & \\
& & & $* * *_{-}$ & $* * *-$ & & & \\
BTEN & $* *-0.308$ & -0.021 & 0.711 & 0.447 & 1 & & \\
FSIZE & $* * * 0.673$ & $* * * 0.448$ & 0.220 & 0.262 & 0.052 & 1 & \\
PROF & -0.148 & 0.254 & $* *-0.428$ & $* *-0.367$ & $* * * 0.708$ & 0.059 & 1 \\
\hline
\end{tabular}

$* * *$ significant at 0.01 level, ${ }^{* *}$ significant at 0.05 level, $*$ significant at 0.10 level ESG = Environment, Social and Governance, IR = Integrated Reporting, BSIZE = Board Size, BIND = Board Independence, $\mathrm{BTEN}=$ Board Tenure, FSIZE $=$ Bank Size, PROF $=$ Profitability

The correlation coefficient matrix can also be used to examine multicollinearity issue that may presence in the regression analysis. Hair et al. (2014) suggest that multicollinearity problem presences if a correlation coefficient between variables is 0.90 and above. Since the highest correlation is 0.708 , the correlations among the variables of this study do not exceed the threshold suggested by Hair et al. (2014), implying that multicollinearity is not an issue in this study.

\section{Multiple Regression}

This study employed multiple regression analysis to examine the influence of IRD on environment, social and governance (ESG) using the following regression model after controlling for the banks' board size, board independence, board tenure, banks' size and profitability:

$\mathrm{ESGit}=\alpha+\beta_{1} I R D_{i t}+\beta_{2} \mathrm{BSIZE}_{i t}+\beta_{3} \mathrm{BIND}_{i \mathrm{t}}+\beta_{4} \mathrm{BTEN}_{\mathrm{it}}+\beta_{5} \mathrm{FSIZE}_{i \mathrm{t}}+\beta_{6} \mathrm{PROF}_{i \mathrm{t}}+\varepsilon_{i \mathrm{t}}$

Table 6: Multiple Regression

\begin{tabular}{lccl}
\hline & Coefficients & t Stat & P-value \\
\hline Intercept & -234.706 & -4.733 & 0.000 \\
IRD & $\mathbf{1 . 1 8 8}$ & $\mathbf{4 . 0 9 9}$ & $\mathbf{0 . 0 0 0 * * *}$ \\
BSIZE & -1.419 & -1.173 & 0.249 \\
BIND & 0.128 & 1.0103 & 0.320 \\
BTEN & $\mathbf{- 1 . 1 1 2}$ & $\mathbf{- 1 . 7 6 5}$ & $\mathbf{0 . 0 8 9 *}$ \\
FSIZE & $\mathbf{1 0 . 1 2 9}$ & $\mathbf{4 . 4 5 9}$ & $\mathbf{0 . 0 0 0 * * *}$ \\
PROF & -6.747 & -0.659 & 0.515 \\
\hline
\end{tabular}

Adj. R square $\quad 0.725$

Fvalue $18.170 * * *$

***significant at 0.01 level, ${ }^{* *}$ significant at 0.05 level, * significant at 0.10 level

ESG = Environment, Social and Governance, IR = Integrated Reporting, BSIZE = Board Size, $\mathrm{BIND}=$ Board Independence, $\mathrm{BTEN}=$ Board Tenure, $\mathrm{FSIZE}=$ Bank Size, $\mathrm{PROF}=$ Profitability 
INTERNATIONAL JOURNAL OF ACADEMIC RESEARCH IN ACCOUNTING, FINANCE AND MANAGEMENT SCIENCES

Vol. 11, No. 3, 2021, E-ISSN: 2225-8329 @ 2021 HRMARS

Table 6 presents the multiple regression result for the relationship between integrated reporting disclosure and environment, social and governance score after controlling for board of directors' attributes and banks'-specific characteristics. As depicted in Table 6, there is a positive and significant relationship between IRD and ESG score $(t=4.099)$. This result support the hypothesis of the study by providing empirical evidence that banks that have higher degree of IRD are more likely to have higher ESG score. Consistent with Conway (2019), the findings suggests that the integration of reporting produced by Malaysian banks have favourably induced the management to broaden their decision-making consideration to incorporate more environmental, social and governance areas in their reports which subsequently affect their ESG score performance.

In this study, several control variables namely board size, board independence, board tenure, bank size and profitability have been considered. The findings of this study suggest that even though board tenure and bank size have significant influence on the ESG score, board size, board independence and profitability of the bank have no influence on the ESG score. Due to sufficient resources and facilities, bigger banks are able to report more information about their investment in ESG. Hence the ESG score is positively influenced by the size of the bank which is consistent with Shakil et al., (2020). In line with Sankara et al. (2017), the results show that there is no significant relationship between board size (BSIZE) and ESG score. Contrary to Chau and Gray (2010), board with higher proportions of independent directors does not inspire higher ESG score and greater commitment in ESG activities. Similar to Shonhadji (2018) and Welbeck et al. (2017), it is found that the profitability level has negative and insignificant relationship with environmental disclosure. This study does not support the argument that profitable banks are encouraged to disclose more information on ESG to enhance their reputation (Welbeck et al., 2017).

\section{Conclusion}

This study observes the impact of IRD and other control variables, namely the characteristics of board of directors (size, independence, tenure), company size and profitability, on ESG. The study discovers significant relationship between IRD, board tenure, bank size and ESG. The results suggest the degree of IRD, board tenure and bank size affect the ESG score performance of Malaysian banks.

Despite the significant findings obtained in this study that could contribute significantly to the literature of IRD and ESG, nevertheless, this study is not without any shortcomings. This study has only concentrated on banks that have information in the ESG database. Hence, future study could consider other industries as well. Further, the results found in this study could assist the stakeholders in their decision making and these results provide evidences to the authority to encourage all listed companies in preparing IR and to maintain an acceptable ESGscore, as the presence of IR and ESG bring much benefits to various parties.

\section{Acknowledgements}

The authors would like to thank the financial support granted by Universiti Teknologi MARA 
INTERNATIONAL JOURNAL OF ACADEMIC RESEARCH IN ACCOUNTING, FINANCE AND

MANAGEMENT SCIENCES

Vol. 11, No. 3, 2021, E-ISSN: 2225-8329 @ 2021 HRMARS

\section{References}

Abdul Rahman, R., \& Alsayegh, M. F. (2021). Determinants of Corporate Environment, Social and Governance (ESG) Reporting among Asian Firms. Journal of Risk and Financial Management, 14(4), 167. https://doi.org/10.3390/jrfm14040167

Aboud, A., \& Diab, A. (2018). The impact of social, environmental and corporate governance disclosures on firm value: Evidence from Egypt. Journal of Accounting in Emerging Economies, 8(4), 442-458. https://doi.org/10.1108/JAEE-08-2017-0079

Accountants Today, P. T. (2014). Integrated Reporting in Malaysia. 27(4), 38-41.

Akhtaruddin, M., Hossain, M. A., Hossain, L., \& Yao, L. (2009). Corporate Governance and Voluntary Disclosure in Corporate Annual Reports of Malaysian Listed Firms The Evolution of Financial Reporting in Kazakhstan View project. Journal of Applied Management Accounting Research, 7(1).

https://www.researchgate.net/publication/237435847

Aldasoro, I., Fender, I., Hardy, B., \& Tarashev, N. (2020). Effects of Covid-19 on the Banking Sector: the Market's Assessment. In BIS Bulletin (Issue 12).

Anazonwu, H. O., Egbunike, F. C., \& Gunardi, A. (2018). Corporate Board Diversity and Sustainability Reporting: A Study of Selected Listed Manufacturing Firms in Nigeria. Indonesian Journal of Sustainability Accounting and Management, 2(1), 65. https://doi.org/10.28992/ijsam.v2i1.52

Baron, R. (2014). The Evolution of Corporate Reporting for Integrated Performance. In Organisation for Economic Co-operation and Development (OECD) (Issue June). https://www.oecd.org/sdroundtable/papersandpublications/The Evolution of Corporate Reporting for Integrated Performance.pdf

Barua, B., \& Barua, S. (2020). COVID-19 Implications for Banks The Case of an Emerging Economy With a Weak Financial System.

https://doi.org/http://dx.doi.org/10.2139/ssrn.3646961

Bătae, O. M., Dragomir, V. D., \& Feleagă, L. (2021). The relationship between environmental, social, and financial performance in the banking sector: A European study. Journal of Cleaner Production, 290. https://doi.org/10.1016/j.jclepro.2021.125791

Bernardi, C., \& Stark, A. W. (2018). Environmental, social and governance disclosure, integrated reporting, and the accuracy of analyst forecasts. British Accounting Review, 50(1), 16-31. https://doi.org/10.1016/j.bar.2016.10.001

Branco, M., \& Rodrigues, L. (2007). Placing stakeholder theory within the debate on corporate social responsibility. Journal of Business Ethics and Organization Studies, 12(1), 5-15. https://jyx.jyu.fi/bitstream/handle/123456789/25388/ejbo_vol12_no1_pages_5-

15. pdf?sequence $=1$ \&isAllowed $=y$

Chau, G., \& Gray, S. J. (2010). Family ownership, board independence and voluntary disclosure: Evidence from Hong Kong. Journal of International Accounting, Auditing and Taxation, 19(2), 93109. https://doi.org/10.1016/j.intaccaudtax.2010.07.002

Cheng, E. C. M., \& Courtenay, S. M. (2006). Response to discussion of "board composition, regulatory regime and voluntary disclosure." International Journal of Accounting, 41(3), 293-294. https://doi.org/10.1016/j.intacc.2006.07.003

Conway, E. (2019). Quantitative impacts of mandatory integrated reporting. Journal of Financial Reporting and Accounting, 17(4), 604-634. https://doi.org/10.1108/JFRA-08-2018-0066

Dhole, S., Mishra, S., \& Pal, A. M. (2019). Efficient working capital management, financial constraints 
INTERNATIONAL JOURNAL OF ACADEMIC RESEARCH IN ACCOUNTING, FINANCE AND

MANAGEMENT SCIENCES

Vol. 11, No. 3, 2021, E-ISSN: 2225-8329 @ 2021 HRMARS

and firm value: A text-based analysis. Pacific Basin Finance Journal, 58(October), 101212. https://doi.org/10.1016/j.pacfin.2019.101212

Eccles, R. G., \& Krzus, M. P. (2010). One Report: Integrated Reporting for a Sustainable Strategy. . John Wiley \& Sons.

Freeman, R. E. (1984). Strategic Management: A Stakeholder Approach. Pitman Publishing.

Freeman, R. E. (2010). Strategic management: A stakeholder approach. Cambridge University Press. https://books.google.com.my/books?hl=en\&lr=\&id=NpmA_qEiOpkC\&oi=fnd\&pg=PR5\&dq=Fre eman,+R.E.,+1984.+Strategic+Management:+A+Stakeholder+Approach.+\&ots=61egE5J8TP\&sig $=601 B Z p z-D 9 r B J x B 8 U F a G L W A J R z k \&$ redir_esc=y\#v=onepage\& $q \& f=f a l s e$

Frias-Aceituno, J. V, Rodriguez-Ariza, L., \& Garcia-Sanchez, I. M. (2013). The Role of the Board in the Dissemination of Integrated Corporate Social Reporting. Corporate Social Responsibility and Environmental Management, 20(4), 219-233. https://doi.org/https://doi.org/10.1002/csr.1294

García-Sánchez, I. M., \& Noguera-Gámez, L. (2017). Integrated information and the cost of capital. International Business Review, 26(5), 959-975.

https://doi.org/10.1016/j.ibusrev.2017.03.004

Giannarakis, G. (2014). The determinants influencing the extent of CSR disclosure. International Journal of Law and Management, 56(5), 393-416.

https://doi.org/10.1108/IJLMA-05-2013-0021

Godfrey, P. C. (2005). The relationship between corporate philanthropy and shareholder wealth: $A$ risk management perspective. Academy of Management Review, 30(4), 777-798. https://doi.org/10.5465/AMR.2005.18378878

Gul, F. A., \& Leung, S. (2004). Board leadership, outside directors' expertise and voluntary corporate disclosures. Journal of Accounting and Public Policy, 23(5), 351-379. https://doi.org/10.1016/j.jaccpubpol.2004.07.001

Hair, J. F., Black, W. C., Babin, B. J., \& Anderson, R. E. (2014). Multivariate data analysis (7th (ed.)). Pearson Education.

Handajani, L., Subroto, B., Sutrisno, T., \& Saraswati, E. (2014). Does board diversity matter on corporate social disclosure? An Indonesian evidence. Journal of Economics and Sustainable Development, 5(9), 8-16.

Husted, B. W., \& de Sousa-Filho, J. M. (2019). Board structure and environmental, social, and governance disclosure in Latin America. Journal of Business Research, 102(February 2018), 220227. https://doi.org/10.1016/j.jbusres.2018.01.017

IIRC. (2021). The International IR Frameworks. https://integratedreporting.org/wpcontent/uploads/2021/01/InternationallntegratedReportingFramework.pdf

Jensen, J. C., \& Berg, N. (2012). Determinants of Traditional Sustainability Reporting Versus Integrated Reporting. An Institutionalist Approach. Business Strategy and the Environment, 21(5), 299-316. https://doi.org/10.1002/bse.740

Karamanou, I., \& Vafeas, N. (2005). The association between corporate boards, audit committees, and management earnings forecasts: An empirical analysis. Journal of Accounting Research, 43(3), 453-486. https://doi.org/10.1111/j.1475-679X.2005.00177.x

Khaled, R., Ali, H., \& Mohamed, E. K. A. (2021). The Sustainable Development Goals and corporate sustainability performance: Mapping, extent and determinants. Journal of Cleaner Production, 311(May), 127599. https://doi.org/10.1016/j.jclepro.2021.127599

Kılıç, M., \& Kuzey, C. (2018). Determinants of forward-looking disclosures in integrated reporting. 
INTERNATIONAL JOURNAL OF ACADEMIC RESEARCH IN ACCOUNTING, FINANCE AND

MANAGEMENT SCIENCES

Vol. 11, No. 3, 2021, E-ISSN: 2225-8329 @ 2021 HRMARS

Managerial Auditing Journal, 33(1), 115-144. https://doi.org/10.1108/MAJ-12-2016-1498

Krippendorff, K. (2004). Content Analysis- An Introduction to Its Methodology. Sage Publications, Beverly Hills, CA.

https://books.google.com.my/books?hl=en\&lr=\&id=nE1aDwAAQBAJ\&oi=fnd\&pg=PP1\&dq=Kri ppendorff,+K.+(2004).+Content+Analysis-

+ An+Introduction+to+Its+Methodology,+Sage+Publications,+Beverly+Hills,+CA\&ots=yZafXqkL9 $x \& s i g=d D y V J k B U A 6 t 9 r \mid g U w D A y J a i 3 X 0 Q \&$ redir_esc $=y \# v=0$

Li, B., Zheng, W., \& Ma, C. (2019). Do bullet trains affect earnings management? Evidence from China. Finance Research Letters, 31(April 2018), 498-501. https://doi.org/10.1016/j.frl.2018.12.027

Sotorrío, L., \& Fernández-Sánchez, J. L. (2010). Corporate Social Reporting for Different Audiences: The case of multinational corporations in Spain. Corporate Social Responsibility and Environmental, 17, 272-283.

https://onlinelibrary.wiley.com/doi/abs/10.1002/csr.215

Marston, C., \& Polei, A. (2004). Corporate reporting on the Internet by German companies. International Journal of Accounting Information Systems, 5(3), 285-311. https://doi.org/10.1016/j.accinf.2004.02.009

Orazalin, N. (2019). Corporate governance and corporate social responsibility (CSR) disclosure in an emerging economy: evidence from commercial banks of Kazakhstan. Corporate Governance (Bingley), 19(3), 490-507. https://doi.org/10.1108/CG-09-2018-0290

Ozcan, I. C. (2019). Determinants of Environmental, Social, and Governance Disclosure Performance of Publicly Traded Airports. International Journal of Transport Economics, 46(3), 77-92. https://www.researchgate.net/publication/337720367

Pallant, J. (2020). A step by step guide to data analysis using IBM SPSS (7th ed.). Routledge.

Prencipe, A. (2004). Proprietary Costs and Determinants of Voluntary Segment Disclosure: Evidence from Italian Listed Companies. The European Accounting Review, 13(2), 319-340. https://www.tandfonline.com/doi/abs/10.1080/0963818042000204742

Qiu, Y., Shaukat, A., \& Tharyan, R. (2016). Environmental and social disclosures: Link with corporate financial performance. British Accounting Review, 48(1), 102-116. https://doi.org/10.1016/j.bar.2014.10.007

Refiniti Eikon Datastream. (2021). Available at:

https://www.refinitiv.com/content/dam/marketing/en_us/documents/methodology/refinitivesg-scores-methodology.pdf

Riyadh, H. A., Sukoharsono, E. G., \& Alfaiza, S. A. (2019). The impact of corporate social responsibility disclosure and board characteristics on corporate performance. Cogent Business and Management, 6(1). https://doi.org/10.1080/23311975.2019.1647917

Rutherford, M. A., \& Buchholtz, A. B. (2007). Investigating the relationship between board characteristics and board information. Corporate Governance: An International Review, 15, 576584.

Samaha, K., Dahawy, K., Hussainey, K., \& Stapleton, P. (2012). The extent of corporate governance disclosure and its determinants in a developing market: The case of Egypt. Advances in Accounting, 28(1), 168-178. https://doi.org/10.1016/j.adiac.2011.12.001

Sankara, J., Lindberg, D. L., \& Nowland, J. (2017). Are Board Governance Characteristics associated with Ethical Corporate Social Responsibility Disclosures? The Case of the Mandatory Conflict Minerals Reporting Requirement. Journal of Leadership, Accountability and Ethics, 14(3), 101- 
INTERNATIONAL JOURNAL OF ACADEMIC RESEARCH IN ACCOUNTING, FINANCE AND

MANAGEMENT SCIENCES

Vol. 11, No. 3, 2021, E-ISSN: 2225-8329 @ 2021 HRMARS

116.

https://search.proquest.com/docview/1963073972?accountid=152256\%0Ahttps://search.pro quest.com/docview/1963073972?accountid=14338\%0Ahttps://tilburguniversity.on.worldcat.o rg/atoztitles/link?genre=article\&issn=\&title=Journal+of+Leadership\%2C+Accountability+an

Shakil, M. H. (2021). Environmental, social and governance performance and financial risk: Moderating role of ESG controversies and board gender diversity. Resources Policy, 72(May), 102144. https://doi.org/10.1016/j.resourpol.2021.102144

Shakil, M. H., Tasnia, M., \& Mostafiz, M. I. (2020). Board gender diversity and environmental, social and governance performance of US banks: moderating role of environmental, social and corporate governance controversies. International Journal of Bank Marketing, 39(4), 661-677. https://doi.org/10.1108/IJBM-04-2020-0210

Shiah-Hou, S. R., \& Cheng, C. W. (2012). Outside director experience, compensation, and performance. Managerial Finance, 38(10), 914-938.

https://doi.org/10.1108/03074351211255146

Shonhadji, N. (2018). (2018). Financial performance to environmental disclosure with environmental performance as moderation. International Journal of Research Science \& Management, 5(8), 183-191.

Smith, H. J., \& Hasnas, J. (1999). Ethics and information systems: the corporate domain. MIS Quart, 23(1), 109-127. https://doi.org/10.1145/569905.569908

Songini, L., Pistoni, A., Tettamanzi, P., Fratini, F., \& Minutiello, V. (2021). Integrated reporting quality and BoD characteristics: an empirical analysis. In Journal of Management and Governance (Issue 0123456789). Springer US. https://doi.org/10.1007/s10997-021-09568-8

Stubbs, W., \& Higgins, C. (2012). Sustainability and Integrated Reporting : A Study of the Inhibitors and Enablers of Integrated Reporting. Chartered Accountants Australia and New Zealand, December, 1-2.

Umar, Z., Kenourgios, D., \& Papathanasiou, S. (2020). The static and dynamic connectedness of environmental, social, and governance investments: International evidence. Economic Modelling, 93(July), 112-124. https://doi.org/10.1016/j.econmod.2020.08.007

Velte, P. (2017). Does Board Composition Have an Impact on CSR Reporting? Problems and Perspectives in Management,. 15(2), 19-35. https://www.ceeol.com/search/articledetail ?id=620314

Welbeck, E. E., Owusu, G. M. Y., Bekoe, R. A., \& Kusi, J. A. (2017). Determinants of environmental disclosures of listed firms in Ghana. International Journal of Corporate Social Responsibility, 2(11), 1-12. https://doi.org/10.1186/s40991-017-0023-y 